\title{
Morphological and molecular characters of Cherax quadricarinatus (von Martens, 1868) from Sermo Reservoir and Tambakboyo Retention Basin, Daerah Istimewa Yogyakarta, Indonesia
}

\author{
Rury Eprilurahman ${ }^{1 *}$, Aplina Krismutia Simarmata ${ }^{1}$, Lukman Hakim $^{1}$, Trijoko $^{1}$ \\ ${ }^{1}$ Laboratory of Animal Systematics, Faculty of Biology, Universitas Gadjah Mada \\ Jl. Teknika Selatan, Sekip Utara, Sleman, D.I.Yogyakarta, Indonesia. 55281 \\ *Email: rurybiougm@ugm.ac.id
}

\begin{abstract}
The Australian red claw freshwater crayfish, Cherax quadricarinatus, is one of the most widely distributed and cultivated freshwater crayfish due to its high tolerance towards various environmental conditions. Native to North Australia and South Papua New Guinea, this crayfish was found in Tambakboyo Retention Basin in 2016 and Sermo Reservoir in 2019. This research was aimed to identify the morphological and molecular characters of C. quadricarinatus collected from Sermo Reservoir and Tambakboyo Retention Basin, Yogyakarta. The genetic information of the samples was compared to Australian red claw freshwater crayfish currently available. The methodology used for this research is morphological, morphometrical, meristic identification, and molecular identification using the PCR method. The primer used to be 1471 primers as the forward primer and 1472 primers as the reverse primer. In conclusion, all six specimens obtained were identified to be $C$. quadricarinatus. Morphological analysis using UPGMA showed that all specimens were formed one big cluster and had the highest similarity index (1.00). Molecular analysis using BLAST showed that specimen from Sermo Reservoir was $98.96 \%$ identical to $C$. quadricarinatus and specimen from Tambakboyo Retention Basin was $100 \%$ identical to $C$. quadricarinatus. Thus, based on their morphological and molecular character, all samples of this study were $C$. quadricarinatus. This finding also contributes to the distribution information of $C$. quadricarinatus in Daerah Istimewa Yogyakarta.
\end{abstract}

Keywords: Cherax quadricarinatus; molecular 16S; morphological character; morphometric; Daerah Istimewa Yogyakarta

Article History: Received 22 October 2020; Received in revised form 23 December 2020; Accepted 30 May 2021; Available online 30 June 2021

How to Cite This Article: Eprilurahman R, Aplina Krismutia Simarmata AK, Hakim L, Trijoko T. 2021. Morphological and molecular characters of Cherax quadricarinatus (von Martens, 1868) from Sermo Reservoir and Tambakboyo Retention Basin, Daerah Istimewa Yogyakarta, Indonesia. Biogenesis: Jurnal Ilmiah Biologi. vol 9(1): 18-25. doi: https://doi.org/10.24252/bio.v9i1.16612.

\section{INTRODUCTION}

Freshwater

crayfish, Cherax

quadricarinatus is an Australian red claw freshwater crayfish and native in North Queensland, Australia, and South Papua New Guinea (Patoka et al., 2018). It's distributed almost all over the world, especially in tropical countries, and commonly used in the aquaculture industry. In 1987, crayfish culture was began in Queensland, Australia, and this industry becomes developed, followed by growth in aquaculture technology (Rigg et al., 2020). The crayfish trade has grown since the mid-1990s, and around 30 crayfish varieties have been sold, used as aquaculture commodities in several countries around the world. Based on crayfish introduction data in various countries, animal trafficking is one of the principal patterns that lead to introducing the global non-native crayfish species (Putra et al., 2018). One of the causes for Australian red claw freshwater crayfish today can be found practically all over the world.

In Indonesia, $C$. quadricarinatus is endemic in Papua Province, near the Western Region of New Guinea. The most remarkable communities of freshwater crayfish in the world inhabit the Wissel Lakes in Papua Province, Indonesia. The Wissel Lakes are classified as ancient lakes and consists of three mountain lakes: Paniai Lake, Tage Lake, and Tigi Lake (Eprilurahman, 2014). The climate match between Papua's region and Indonesia's region makes this crayfish easy to cultivate and adapt when introduced in different places in Indonesia (Patoka et al., 2016). Sermo Reservoir is an artificial multipurpose lake to support agricultural development, clean water distribution through the population in Kulon Progo, as a tourist attraction, and sometimes for 
fisheries activities (Sudarmadji \& Widyastuti, 2014; Rahayu et al., 2016). Tambakboyo Retention Basin is an artificial water ecosystem constructed by the Yogyakarta Government to provide water reserves, groundwater catchment, and irrigation for Bantul District in Yogyakarta (Purwanto et al., 2017; Sriyono et al., 2019).

Red claw freshwater crayfish was discovered at Sermo Reservoir in 2019 and Tambakboyo Retention Basin in 2016. The Sermo Reservoir officially operated in 1996. The fisherman explained the freshwater crayfish was discovered from 2010 to 2011, but in 2012 there was a big increase in crayfish. Tambakboyo Retention Basin began to operate in 2009 and followed by the following year, locals discovered the crayfish. The introduction of crayfish can not escape from aquaculture and animal trade activity (Putra et al., 2018). Like the case of introduction worldwide, these crayfish become wild populations because of the unintentional or intentional release by local residents. Based on Patoka et al. (2018), the distribution of $C$. quadricarinatus in Indonesia were in Batam and Bintan Island (Kepulauan Riau), Java, Kalimantan (Borneo), Sulawesi, and Sumatera (Fig. 1). C. quadricarinatus also has been successfully introduced to and has established feral populations within several tropical and subtropical countries, including Jamaica, Mexico, Puerto Rico, Singapore, and South Africa (Patoka et al., 2016). The detailed information about freshwater crayfish production in Asian countries is mostly not available. The commercial production of red claw was started in the late 1980s (Patoka et al., 2016). Unfortunately, the mechanism and history introduction of $C$. quadricarinatus in Indonesia are currently unknown (Patoka et al., 2018), so does in Daerah Istimewa Yogyakarta. The species have increased in popularity for human consumption and ornamental purposes in Indonesia (Patoka et al., 2018).

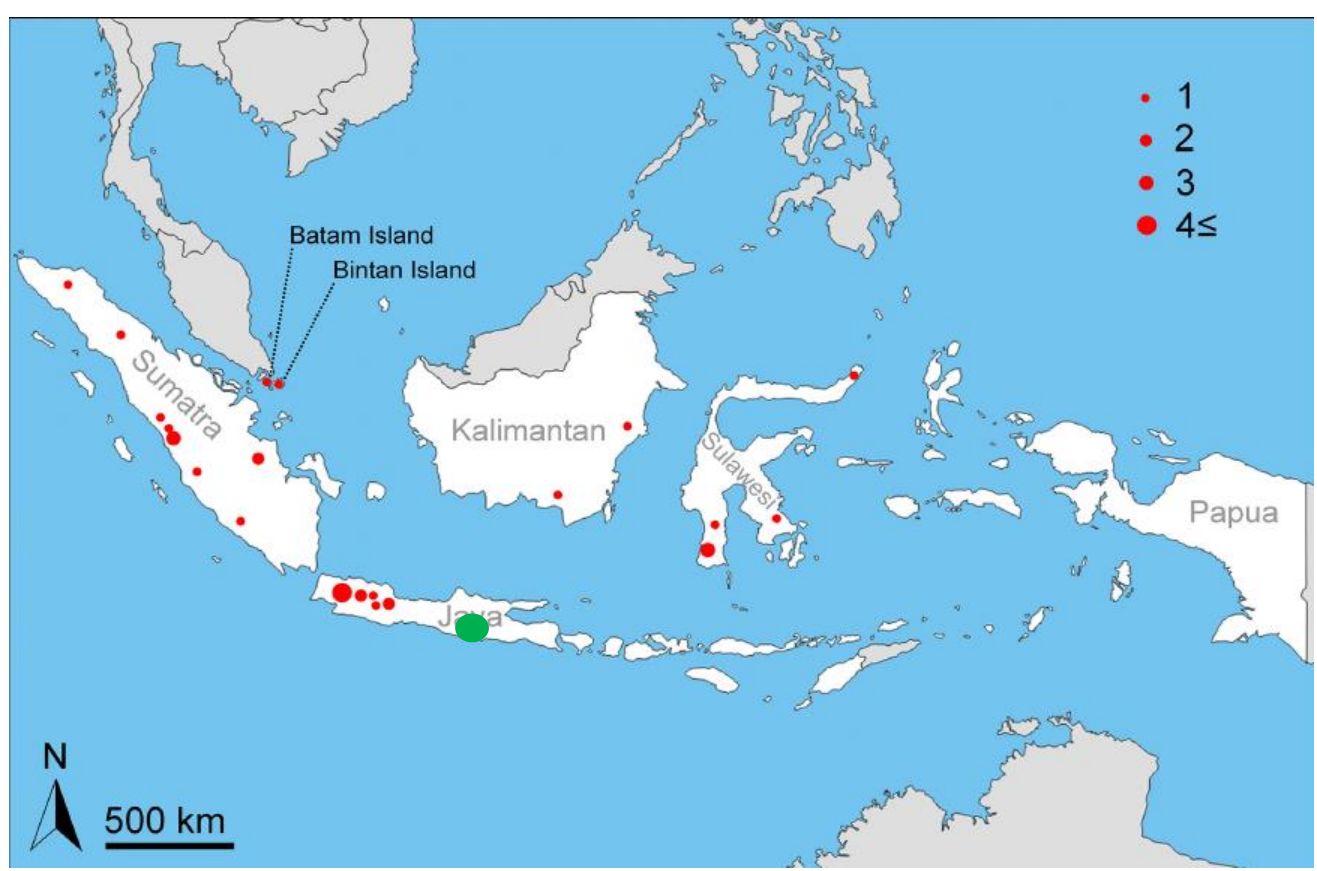

Fig. 1. The distribution map of Cherax quadricarinatus in Indonesia with red mark. Green mark for crayfish in Daerah Istimewa Yogyakarta (Patoka et al., 2018 with modification).

The morphological character can be used for species identification but generally still cannot construct taxonomic classification yet. For some species, morphological identification sometimes is not effective and less precise. Accurate species identification is crucial in the conservation program, especially for endemic or endangered species (De Grave et al., 2014). Technological development was used to understand the species' evolution more effectively and accurately associated with specific conservation and population structure 
(Chapman et al., 2011; Han et al., 2016; Khan et al., 2016). One method used for molecular characterization was developed by researchers for the red claw freshwater crayfish is DNA barcoding from the mitochondria 16S rRNA. Molecular characterization is the basic concept for constructing the taxonomy and understand the evolutionary relationship between organisms to reach the correct identification method (Eprilurahman, 2014; Skuza et al., 2016; Glon et al., 2018; Zhu et al., 2019). This study's results are expected to complete genetic information of red claw freshwater crayfish that can support its conservation in Indonesia and contribute to understanding the distribution of $C$. quadricarinatus in Yogyakarta. This study aims to know the morphological and molecular character of $C$. quadricarinatus from Sermo Reservoir and Tambakboyo Retention Basin, Yogyakarta. Furthermore, this study shows better and correct methods of identification to produce accurate and effective data.

\section{MATERIALS AND METHODS}

The study was carried out in the Sermo Reservoir, Kulon Progo, Yogyakarta (7'49'18.3'LS and 110 07'22.4'BT) on March 14, 2019 and March 19, 2020 and in Tambakboyo Retention Basin, Yogyakarta (7'45'20.3'LS and $\left.110^{\circ} 24^{\prime} 56.7^{\prime \prime} \mathrm{BT}\right)$ on January 19, 2016 and March 13, 2020. The sample used in this study were two freshwater crayfish Cherax quadricarinatus species in 2016 and 2019, and four crayfish from independent sampling in 2020. Materials for lobster preservation use alcohol $96 \%$. The tools used for morphological identification were DSLR camera, mini studio, ruler, caliper, and the key identification journal of $C$. quadricarinatus.

Procedures of morphological and molecular identification. Morphological identification was carried out using the identification key of Cherax sp. by Riek (1969). Data consist of morphological, morphometrical, and meristic data. The morphological data were observed included the diagnostic characters of lobsters at the family, genus, and species levels. Crayfish morphometrical data followed Abinawanto et al. (2018), which was obtained by measuring lobster body parts, including the head, chest, abdomen, and tail, using a caliper with an accuracy of $0.01 \mathrm{~mm}$. Meristic data followed Austin (1996), which is obtained by counting the number of components of a predetermined crayfish. Total genomic DNA was extracted from lobster abdomen tissue (50-100 mg) following the instructions of QIAGEN DNeasy Blood \& Tissue Kits. DNA amplification using primers 1471 ( $5^{\prime} \mathrm{CCTG}$ TTTANCAAAAACAT$\left.3^{\prime}\right)$ and 1472 (5' AGATAGAAACCAACCTGG$3^{\prime}$ ) (Crandall \& Fitzpatrick, 1996) based on the Bioline MyTaq Red Mix Protocol. DNA amplification was carried out using a PCR machine using five stages, pre-denaturation at $95^{\circ} \mathrm{C}$, denaturation at $95^{\circ} \mathrm{C}$, annealing at $50^{\circ} \mathrm{C}$, extension at $72^{\circ} \mathrm{C}$, and final extension at $72^{\circ} \mathrm{C}$. PCR product of each sample from amplification was sequencing.

Data analysis. Data analysis includes morphological and molecular analysis. The morphological analysis was obtained with morphological characters converted into a binary matrix (0-1). If an individual owned the observed morphological character trait, the trait was written with the number 1 . A trait that an individual did not own was written as 0 . The quantitative morphometrical character was analyzed by SPSS 26 version program with One-way Anova Test to make the data homogenous. Values within the deviation range were written as 1 , and those outside the deviation range were written as 0 . The data matrix was created with Ms. Excel 2007. Clustering analysis uses the UPGMA (Unweighted Pair Group with Arithmetic Average) method with the MVSP 3.1 (MultiVariate Statistical Package) program. In molecular analysis, a positive band was obtained then sent to be sequenced at PT. Genetika Science Indonesia, Jakarta, Indonesia. The sequence was edited using Genestudio software then matched with the Genbank sequence using the BLAST method. The sequences verified as $C$. quadricarinatus species were then analyzed for genetic distance, genetic variation, polymorphic sites, and phylogeny tree. 


\section{RESULTS AND DISCUSSION}

Morphological identification. In this study, observation and morphological analysis were carried out. Cherax quadricarinatus has very large first pereopod (Table 1). This structure is related to their habitual life, burrow the ground. These crayfish can be found in rivers and ponds, drying all year around or on surfaces with limited water. This habit of Australian freshwater crayfish is an adaptation behavior to survive during the dry season and dry climate (Eprilurahman, 2014). The crayfish will dig up the surface as deep as possible until the water was found, then they will enter the excavation and cover the hole with soil (Crandall \& De Grave, 2017). There are also groups of crayfish that live permanently in rivers or lakes without digging the ground and surviving on the surface of the river with little water. This statement supports the results of our sampling in the field. These crayfish were found around the soil root of the plant and in the excavation of the soil that was not too deep, revealing half of its body.

C. quadricarinatus is a member of Parastacidae family, which has diagnostic characters in cervical grooves and branchiocardial grooves that fused in the cephalothorax laterally (Table 1). This character is the main feature that inherited from the ancestor of the family Parastacidae. At the genus level, the diagnostic character of the Cherax genus is their tail has a transparent membrane and without indication of sutures (Table 1) (Crandall \& De Grave, 2017). The suture is kind of transverse line on the tail of crayfish. The tail with the suture is generally owned by red claw freshwater crayfish from Papua habitat. This feature is a distinctive character from the red claw crayfish of the Australian habitat. The second genus, the diagnostic character, is the male genital organ of crayfish more complex than another genus in this family, and there is no calcification (Table 1) (Crandall \& De Grave, 2017). The genitals of freshwater crayfish can be seen at the base of their pereopods. Male crayfish are characterized by the opening of the genital organs at the base of the fifth pereopod and female crayfish at the base of the third pereopod
(Table 1). At the species level, the diagnostic character of the $C$. quadricarinatus was characterized by the presence of three pairs of rostrum spines. The first spine is in the middle of the rostrum, close to the eye. The secondary morphological character of C. quadricarinatus are male individuals who have a red patch on the first pereopod (Table 1), so it is known as the Australian Red Claw Freshwater Crayfish. The morphological observations show that all specimens in this study are members of the Parastacidae family, Cherax genus, and quadricarinatus species. The identification of the morphological characters of freshwater crayfish can be seen in Table 1 and 2 .

Table 1. The Result of character identification of freshwater crayfish in Sermo Reservoir (SMO) and Tambakboyo Retention Basin (TBY), Yogyakarta.

\begin{tabular}{|c|c|c|c|}
\hline No & Identification characters & SMO & TBY \\
\hline 1 & $\begin{array}{l}\text { The first pereopod very large } \\
\text { and have a red patch for male } \\
\text { individuals }\end{array}$ & $\checkmark$ & $\checkmark$ \\
\hline 2 & $\begin{array}{l}\text { The cervical and } \\
\text { branchiocardial grooves fused } \\
\text { in the cephalothorax laterally }\end{array}$ & $\checkmark$ & $\checkmark$ \\
\hline 3 & $\begin{array}{l}\text { The tail has transparent } \\
\text { membrane and without } \\
\text { indication of sutures }\end{array}$ & $\checkmark$ & $\checkmark$ \\
\hline 4 & $\begin{array}{l}\text { The male genital organ are } \\
\text { more complex and do not have } \\
\text { calcification }\end{array}$ & $\checkmark$ & $\checkmark$ \\
\hline 5 & $\begin{array}{l}\text { The male crayfish are } \\
\text { characterized by the opening of } \\
\text { the genital organs at the base of } \\
\text { the fifth pereopod }\end{array}$ & $\checkmark$ & $\checkmark$ \\
\hline 6 & $\begin{array}{l}\text { The female crayfish are } \\
\text { characterized by the opening of } \\
\text { the genital organs at the base of } \\
\text { the third pereopod }\end{array}$ & $\checkmark$ & $\checkmark$ \\
\hline 7 & $\begin{array}{l}\text { There are three pairs of rostrum } \\
\text { spines }\end{array}$ & $\checkmark$ & $\checkmark$ \\
\hline
\end{tabular}

All freshwater crayfish in this study are adult organisms and can be identified morphologically until species level. Crayfish total is six samples and morphologically identified as $C$. quadricarinatus. Samples of SMO1 and TBY1 were identified morphologically and molecularly as $C$. quadricarinatus species. 
Table 2. The Result of observation and identification of freshwater crayfish in Sermo Reservoir and Tambakboyo Retention Basin, Yogyakarta.

\begin{tabular}{lllll}
\hline No & Sampling Spot & Sample & Species & Information \\
\hline 1 & Sermo 1 & SMO1 & Cherax quadricarinatus & O, complete \\
2 & Sermo 2 & SMO2 & Cherax quadricarinatus & O, complete \\
3 & Sermo 3 & SMO3 & Cherax quadricarinatus & , complete \\
4 & Tambakboyo 1 & TBY1 & Cherax quadricarinatus & , complete \\
5 & Tambakboyo 2 & TBY2 & Cherax quadricarinatus & O, complete \\
6 & Tambakboyo 3 & TBY3 & Cherax quadricarinatus & O, complete \\
\hline
\end{tabular}

Morphological characters analysis in this study was carried out using the numerical phenetic taxonomy method. Numerical phenetic taxonomy approach in general aims to describe the similarity relationship between taxons shown in a dendrogram (Mooi et al., 2011; Laimeheriwa, 2017; Sterner \& Lidgard, 2018). The dendrogram represents the similarity relationship between red claw crayfish in Sermo Reservoir and Tambakboyo Retention Basin visualized in Fig. 2.

The dendrogram results show that the six crayfish samples build one big cluster and have the highest similarity index (1.00). The higher similarity index shows that the genetic relation of all specimens was closer, while the lower similarity index shows that the genetic relationship was further. The value similarity index 1.00 shows the close genetic relation on crayfishes, and there is no difference between all specimens. These results indicate that the samples in the cluster are $C$. quadricarinatus, and this result is supported by the morphological identification results in Table 1 and 2.

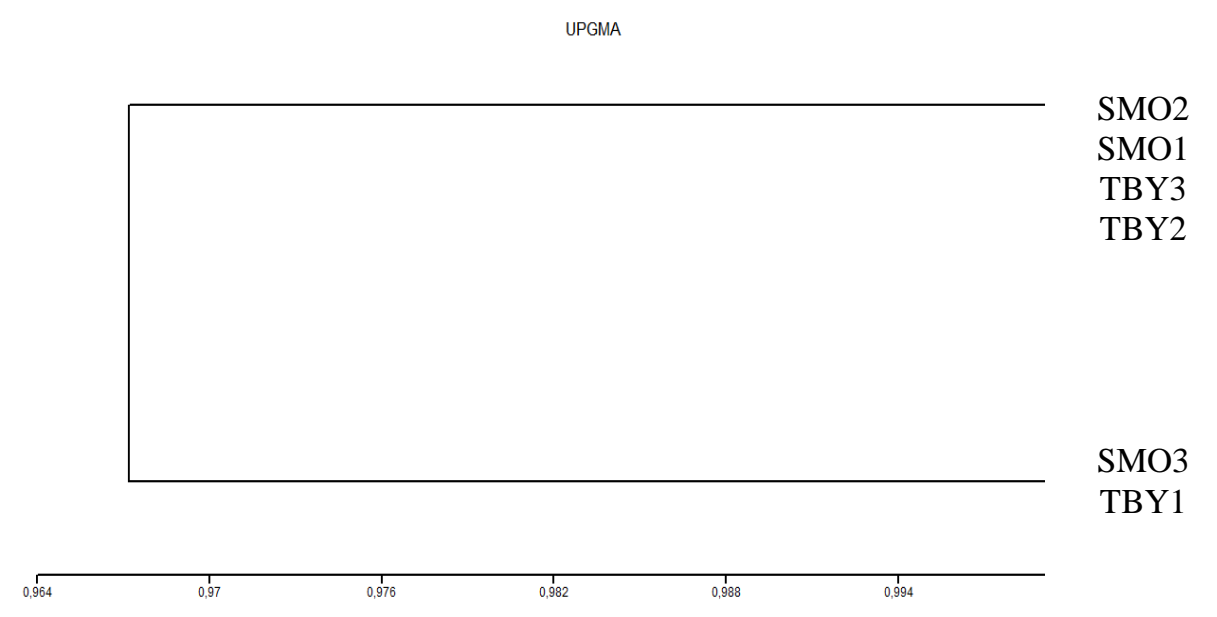

Fig. 2. Dendogram of intraspecies morphological characters phenetic similarity of Cherax quadricarinatus from Sermo Reservoir (SMO) and Tambakboyo Retention Basin (TBY) Yogyakarta (SMO1= $1^{\text {st }}$ Crayfish of Sermo Reservoir; SMO2 $=2^{\text {nd }}$ Crayfish of Sermo Reservoir; SMO3 $=3^{\text {rd }}$ Crayfish of Sermo Reservoir; TBY1= ${ }^{\text {st }}$ Crayfish of Tambakboyo Retention Basin; TBY2 $=2^{\text {nd }}$ Crayfish of Tambakboyo Retention Basin; TBY3 $=3^{\text {rd }}$ Crayfish of Tambakboyo Retention Basin).

Molecular Identification. Similarity analysis with BLAST showed that the individuals sequenced in this study were verified as Cherax quadricarinatus species with more than 98\% (Table 3) from the GenBank database.

A total of two haplotype sequences were obtained in this study and deposited in the
GenBank under the accession number MW600332 and MW600333. This similarity percentage shows that the research sample is similar to the sequence of the GenBank database (Bhattacharjee et al., 2012). The population is considered to have the same gene frequency if the genetic distance is $0 \%$. The population has the same ancestor. 
Table 3. The Result of similarity analysis with BLAST.

\begin{tabular}{|c|c|c|c|c|}
\hline No & NCBI Samples & & Research & TBY1 \\
\hline 1 & $\begin{array}{l}\text { EU244882.1 } C \text {. } \\
\text { quadricarinatus }\end{array}$ & $\begin{array}{l}\text { Query } \\
\text { cover }\end{array}$ & $80 \%$ & $81 \%$ \\
\hline & & Identity & $98.96 \%$ & $100 \%$ \\
\hline 2 & $\begin{array}{l}\text { EU244890.1 C. } \\
\text { quadricarinatus }\end{array}$ & $\begin{array}{l}\text { Query } \\
\text { cover }\end{array}$ & $80 \%$ & $81 \%$ \\
\hline & & Identity & 98.76 & $99.38 \%$ \\
\hline 3 & $\begin{array}{l}\text { EU244888.1 } C \text {. } \\
\text { quadricarinatus }\end{array}$ & $\begin{array}{l}\text { Query } \\
\text { cover }\end{array}$ & $80 \%$ & $81 \%$ \\
\hline & & Identity & $98.76 \%$ & $99.79 \%$ \\
\hline 4 & $\begin{array}{l}\text { EU244887.1 } C \text {. } \\
\text { quadricarinatus }\end{array}$ & $\begin{array}{l}\text { Query } \\
\text { cover }\end{array}$ & $80 \%$ & $81 \%$ \\
\hline & & Identity & $98.76 \%$ & $99.38 \%$ \\
\hline
\end{tabular}

The highest genetic distance shows that the SMO1 sample has genetic differences with TBY1 and GenBank sample EU244882.1 (Table 4). The lowest genetic distance indicated that the TBY1 sample and the GenBank sample EU244882.1 had the same gene frequency (Table 4). This genetic distance and haplotype analysis show that there are genetic differences between the red claw crayfishes of Sermo Reservoir and Tambakboyo Retention Basin, Yogyakarta.

Table 4. Genetic Distance (\%) Cherax quadricarinatus crayfish. Each single sample was compared with a sample from GenBank NCBI. The blue numbers are Standard Error (SE) and the black numbers are genetic distances.

\begin{tabular}{llll}
\hline & EU244882.1 & SMO1 & TBY1 \\
\hline EU244882.1 & & $0.4 \%$ & $0.0 \%$ \\
SMO1 & $0.8 \%$ & & $0.4 \%$ \\
TBY1 & $0.0 \%$ & $0.8 \%$ & \\
\hline
\end{tabular}

The reconstruction results of the phylogeny tree (Fig. 3) show that the SMO1 sample has the closest relation with one GenBank sequence from Papua New Guinea and two GenBank sequences from Australia. Meanwhile, the TBY1 sample has the closest relation with three samples of the GenBank sequences from Australia.

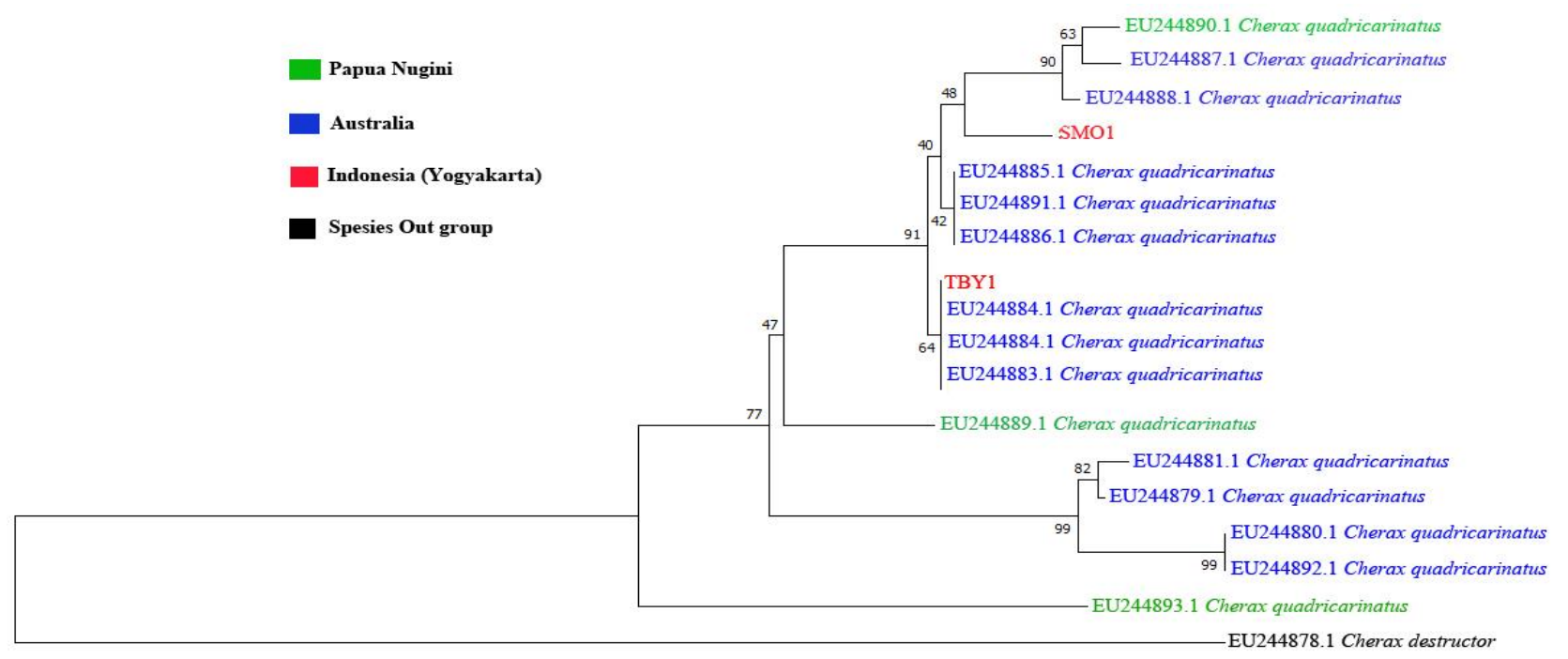

$\longmapsto$

Fig. 3. Phylogeny tree of Cherax quadricarinatus resolved by Neighbor-Joining method with Kimura2 parameter model and bootstrap 1000 replication, number shown bootstrap value.

The reconstruction of this phylogeny tree shows that the red claw freshwater crayfish found in Yogyakarta are Cherax quadricarinatus species which have the same origin as the red claw freshwater crayfish in Australia and Papua New Guinea.

\section{CONCLUSION}

The freshwater crayfish found in Sermo Reservoir and Tambakboyo Retention Basin, D.I. Yogyakarta, Indonesia, were morphologically and molecularly identified as species of Cherax quadricarinatus (von Martens, 1868). The morphological 
identification character of this lobster is shown by the cervical and branchiocardial groove that are fused at the cephalothorax, the tail without suture, the male genital organs have a complex structure without calcified papillae, and the rostrum has three pairs of spines with the first spine in the middle of the rostrum. BLAST molecular analysis shows that the individual samples have more than $99 \%$ similarity with the Genbank database for $C$. quadricarinatus species. The morphological and molecular data from this study are complementary and support each other that the sample of this study is the red claw freshwater crayfish, $C$. quadricarinatus. Further research is needed at different locations to determine the distribution pattern of red claw freshwater crayfish in the Yogyakarta and further investigation regarding the introduction mechanism of $C$. quadricarinatus in Yogyakarta.

\section{ACKNOWLEDGEMENTS}

This research was carried out with the assistance of Faculty of Biology, UGM, which provided research funding to Rury Eprilurahman, S.Si., M.Sc. through the Penelitian Kolaborasi Dosen dan Mahasiswa Tahun 2019 program with the contract number UGM/BI/1703/M/02/05. The author would like to thank The Head of the Laboratory of Genetics \& Breeding and Animal Systematics, Faculty of Biology, UGM who has given permission to use the laboratory facilities, the Macrobrachium of Daerah Istimewa Yogyakarta Team 2019 and Mr. Susilo Irwanjasmoro who gave time and energy during the process of carrying out this research from start to finish both in the field and in the laboratory.

\section{REFERENCES}

Abinawanto A, Hamidah $\mathrm{H}$, Bowolaksono A, Eprilurahman R. 2018. Biometric of freshwater crayfish (Cherax spp.) from Papua and West Papua, Indonesia. Biodiversitas Journal of Biological Diversity. vol 19(2): 489-95. doi: https://doi.org/10.13057/biodiv/d190216.

Austin CM. 1996. Systematics of the freshwater crayfish genus Cherax Erichson (Decapoda: Parastacidae) in northern and eastern Australia: electrophoretic and morphological variation. Australian Journal of Zoology. vol 44(3): 259-96. doi:
https://doi.org/10.1071/ZO9960259.

Bhattacharjee MJ, Laskar BA, Dhar B, Ghosh SK. 2012. Identification and re-evaluation of freshwater catfishes through DNA barcoding. PloS One. vol 7(11): 1-7. doi: https://doi.org/10.1371/journal.pone.0049950.

Chapman BB, Brönmark C, Nilsson JA, Hansson LA. 2011. The ecology and evolution of partial migration. Oikos.vol 120(12): 1764-1775. doi: https://doi.org/10.1111/j.1600-0706.2011.20131.x.

Crandall KA, Fitzpatrick Jr JF. 1996. Crayfish molecular systematics: using a combination of procedures to estimate phylogeny. Systematic Biology. vol 45(1): 1-26. doi: https://doi.org/10.1093/sysbio/45.1.1.

Crandall KA, De Grave S. 2017. An updated classification of the freshwater crayfishes (Decapoda: Astacidea) of the world, with a complete species list. Journal of Crustacean Biology. vol 37(5): 615-53. doi: https://doi.org/10.1093/jcbiol/rux070.

De Grave S, Li CP, Tsang LM, Chu KH, Chan TY. 2014. Unweaving hippolytoid systematics (Crustacea, Decapoda, Hippolytidae): resurrection of several families. Zoologica Scripta. vol 43(5): 496-507. doi: https://doi.org/10.1111/zsc.12067.

Eprilurahman R. 2014. Molecular taxonomy and evolution of freshwater crayfish of the Genus Cherax (Decapoda: Parastacidae) from northern Australia and New Guinea. [Thesis]. Darwin: Charles Darwin University.

Glon MG, Thoma RF, Taylor CA, Daly M, Freudenstein JV. 2018. Molecular phylogenetic analysis of the devil crayfish group, with elevation of Lacunicambarus Hobbs, 1969 to generic rank and a redescription of the devil crayfish, Lacunicambarus diogenes (Girard, 1852) comb. nov.(Decapoda: Astacoidea: Cambaridae). Journal of Crustacean Biology. vol 38(5): 600-613. doi: https://doi.org/10.1093/jcbiol/ruy057.

Han T, Lee W, Lee S, Park IG, Park H. 2016. Reassessment of species diversity of the subfamily Denticollinae (Coleoptera: Elateridae) through DNA barcoding. PloS One. vol 11(2): 1-28. doi: https://doi.org/10.1371/journal.pone.0148602.

Khan S, Nabi G, Ullah MW, Yousaf M, Manan S, Siddique R, Hou H. 2016. Overview on the role of advance genomics in conservation biology of endangered species. International Journal of Genomics. vol 2016: 1-8. doi: https://doi.org/10.1155/2016/3460416.

Laimeheriwa BM. 2017. Phenetic Relationship Study of Gold Ring Cowry, Cypraea Annulus (Gastropods: Cypraeidae) in Mollucas Islands Based on Shell Morphological. Fisheries and Aquaculture Journal. vol 8(3): 1-15. doi: https://doi.org/10.4172/21503508.1000215 .

Mooi RD, Williams DM, Gill AC. 2011. Numerical cladistics, an unintentional refuge for phenetics - a reply to Wiley et al. Zootaxa. vol 2946(1): 17-28. doi: https://doi.org/10.11646/zootaxa.2946.1.5. 
Patoka J, Wardiatno Y, Kuříková P, Petrtýl M, Kalous L. 2016. Cherax quadricarinatus (von Martens) has invaded Indonesian territory west of the Wallace Line: evidences from Java. Knowledge \& Management of Aquatic Ecosystems. vol 417: 1-6. doi: https://doi.org/10.1051/kmae/2016026.

Patoka J, Wardiatno Y, Mashar A, Wowor D, Jerikho R, Takdir M, Purnamasari L, Petrtýl M, Kalous L, Kouba A, Bláha M. 2018. Redclaw crayfish, Cherax quadricarinatus (von Martens, 1868), widespread throughout Indonesia. BioInvasions Record. vol 7(2): 185-189. doi: https://doi.org/10.3391/bir.2018.7.2.11.

Purwanto A, Sriyono E, Sardi S. 2017. Analisis ketersediaan air embung Tambakboyo Sleman DIY. Prosiding Seminar Nasional ReTII ke-12. December 9, 2017. Yogyakarta: Sekolah Tinggi Teknologi Nasional. pp 373-378.

Putra MD, Bláha M, Wardiatno Y, Krisanti M, Jerikho R, Kamal MM, Mojžišová M, Bystřický PK, Kouba A, Kalous L, Petrusek A. 2018. Procambarus clarkii (Girard, 1852) and crayfish plague as new threats for biodiversity in Indonesia. Aquatic Conservation: Marine and Freshwater Ecosystems. vol 28(6): 1434-1440. doi: https://doi.org/10.1002/aqc.2970.

Rahayu S, Dewi U, Fitriana KN. 2016. Pengembangan community based tourism sebagai strategi pemberdayaan ekonomi masyarakat di Kabupaten Kulon Progo, Daerah Istimewa Yogyakarta. Jurnal Penelitian Humaniora. vol 21(1): 1-13.

Riek EF. 1969. The Australian freshwater crayfish (Crustacea: Decapoda: Parastacidae), with descriptions of a new species. Australian Journal of Zoology. vol 17(5): 855-918. doi: https://doi.org/10.1071/ZO9690855.
Rigg DP, Seymour JE, Courtney RL, Jones CM. 2020. A Review of juvenile redclaw crayfish Cherax quadricarinatus (von Martens, 1868) production in aquaculture. Freshwater Crayfish. vol 25(1): 1330. doi: https://doi.org/10.5869/fc.2020.v25-1.013.

Skuza L, Keszka S, Panicz R, Śmietana P. 2016. Molecular characterization of the noble crayfish (Astacus astacus L.) population from Pomeranian lakes (north-western Poland) based on mitochondrial DNA. Knowledge and Management of Aquatic Ecosystems. vol 417: 1-6. doi: http://dx.doi.org/10.1051/kmae/2015046.

Sriyono E, Purwanto A, Sardi NC, Bhakty TE, Biddinika MK. 2019. Assessing the potential of Tambakboyo Retention Basin for raw water supply in the City of Yogyakarta Indonesia. ICASESS Proceedings of the 2nd International Conference on Applied Science, Engineering and Social Sciences. August 7-8, 2019. Yogyakarta: Scitepress. ISBN: 978-989758-452-7. pp 96-100.

Sterner B, Lidgard S. 2018. Moving past the systematics wars. Journal of the History of Biology. vol 51(1): 31-67. doi: https://doi.org/10.1007/s10739-0179471-1.

Sudarmadji S, Widyastuti W. 2014. Dampak dan kendala wisata waduk sermo dari aspek lingkungan hidup dan risiko bencana. Jurnal Teknosains. vol 3(2): 142-157.

Zhu JJ, Ye ZZ, Li CS, Kausar S, Abbas MN, Xiang GH, Qian XY, Dai LS. 2019. Identification and molecular characterization of a novel antilipopolysaccharide factor (ALF) from red swamp crayfish, Procambarus clarkii. International Journal of Biological Macromolecules. vol 132: 43-50.

doi: https://doi.org/10.1016/j.ijbiomac.2019.03.167. 